\title{
Plasma cortisol suppression response in the South African Black population with glaucoma
}

\author{
JEFFREY FREEDMAN, ROBERT DAVID, L. ANDRE VAN DER WALT, AND \\ MAURICE H. LUNTZ \\ From the Glaucoma Clinic, St Fohn Eye Hospital, Baragwanath, South Africa
}

Results of a plasma cortisol suppression test have never been reported in a Black glaucoma population, although there have been reports of tests carried out on glaucomatous patients generally. The results have varied from marked suppression in glaucomatous patients (Becker, Podos, Assef, and Cooper, 1973; Rosenberg and Levene, 1974) to no suppression at all (Schwartz and Levene, 1972).

Glaucoma of all types is prevalent in the South African Bantu (Luntz, 1973). All the patients in this study were seen at the Glaucoma Clinic, St John Eye Hospital, Baragwanath.

\section{Material and methods}

Twenty-five glaucomatous patients were tested and classified according to their age and sex, and type of glaucoma (Table I). A matching group of 19 patients awaiting cataract surgery or corneal grafts were also tested and classified according to their age and sex (Table II). None of the patients had diabetes nor had any been treated with corticosteroids before participation in the trial.

An initial serum cortisol level was estimated between 7.30 and 8.30 a.m., the time at which blood cortisol concentration is highest (Murphy, Engelberg, and Patte, 1963). Patients in both groups were given $15 \mathrm{mg}$ prednisone orally, in three divided doses of $5 \mathrm{mg}$ each one, five, and nine hours after the initial blood tests had been taken. Again at 7.30 and 8.30 the following morning, serum cortisol levels were tested.

Peripheral serum levels of cortisol were determined employing a standard competitive protein binding radioassay. Results were computer-derived using a probit-log transformation plot on a weighted regression line. Reference sera were obtained from Nuclear Medical Systems; these served as controls.

\section{Results}

The serum cortisol level in the control group before and after administration of the oral corticosteroid is given in Table III. The normal level of cortisol

Address for reprints: J. Freedman, FRCS, Department of Ophthalmology. University of Witwatersrand, Hospital Street, Johannesburg 2001, South Africa before administration varied from a low of $6 \cdot 3 \mu \mathrm{g} /$ I00 $\mathrm{ml}$ to a high of $24.9 \mu \mathrm{g} / 100 \mathrm{ml}$, this being within the normal range at 8 a.m. (Murphy, 1967).

The average initial serum cortisol level in the control group was $13.4 \mu \mathrm{g} / \mathrm{r} 00 \mathrm{ml}$.

In 13 of the control patients the blood cortisol level decreased after administration of prednisone, while in six patients there was no decrease or even a minimal increase. The average level of cortisol after administration of prednisone in this group was $10.9 \mu \mathrm{g} / 100 \mathrm{ml}$. This represents an average decrease of $2.5 \mu \mathrm{g} / \mathrm{r} 00 \mathrm{ml}$ in the plasma cortisol level of the control group after the orally administered corticosteroid.

The serum cortisol levels before and after cortisol suppression in the glaucomatous patients are shown in Table IV. The average initial cortisol level was

Table I Age, sex, and type of glaucoma (25 patients)

\begin{tabular}{|c|c|c|c|c|c|c|}
\hline \multirow{3}{*}{$\begin{array}{l}\text { Age range } \\
\text { (years) }\end{array}$} & \multicolumn{6}{|c|}{ Glaucoma } \\
\hline & \multicolumn{2}{|c|}{$\begin{array}{l}\text { Primary } \\
\text { open-angle }\end{array}$} & \multicolumn{2}{|c|}{$\begin{array}{l}\text { Pseudocapsular } \\
\text { exfoliation }\end{array}$} & \multicolumn{2}{|c|}{$\begin{array}{l}\text { Chronic } \\
\text { angle-closure }\end{array}$} \\
\hline & Men & Women & Men & Women & Men & Women \\
\hline $40-50$ & 3 & - & - & 一 & 2 & I \\
\hline $50-60$ & 3 & $\mathbf{I}$ & 2 & $\mathbf{I}$ & I & 一 \\
\hline $60-70$ & 2 & I & 5 & - & - & 一 \\
\hline$>70$ & - & I & I & - & I & - \\
\hline Total & 8 & 3 & 8 & I & 4 & I \\
\hline
\end{tabular}

Table II 19 control subjects

\begin{tabular}{lll}
\hline $\begin{array}{l}\text { Age range } \\
\text { (years) }\end{array}$ & Men & Women \\
& & \\
$40-50$ & 3 & 3 \\
$50-60$ & 2 & 3 \\
$60-70$ & 2 & 4 \\
$>70$ & 2 & - \\
\hline Total & 9 & 10 \\
\hline
\end{tabular}


Table III Plasma cortisol levels in 19 control patients $(\mu \mathrm{g} / \mathrm{1} 00 \mathrm{ml})$ before and after administration of oral cortisone

\begin{tabular}{|c|c|c|c|c|c|c|c|c|c|c|}
\hline Under 60 years & & & & & & & & & & \\
\hline \multicolumn{11}{|c|}{ Plasma cortisol level } \\
\hline $\begin{array}{l}\text { Before cortisone } \\
\text { After cortisone }\end{array}$ & $\begin{array}{l}15 \cdot 4 \\
10 \cdot 7\end{array}$ & $\begin{array}{l}14 \cdot 0 \\
14.6\end{array}$ & $\begin{array}{r}9 \cdot 4 \\
10.7\end{array}$ & $\begin{array}{l}6 \cdot 9 \\
6 \cdot 7\end{array}$ & $\begin{array}{l}13 \cdot 5 \\
12 \cdot 6\end{array}$ & $\begin{array}{r}10 \cdot 7 \\
6 \cdot 5\end{array}$ & $\begin{array}{l}8 \cdot 7 \\
3 \cdot 7\end{array}$ & $\begin{array}{l}15 \cdot 9 \\
10 \cdot 7\end{array}$ & $\begin{array}{l}13 \cdot 3 \\
17 \cdot 5\end{array}$ & $\begin{array}{l}19 \cdot 9 \\
15.5\end{array}$ \\
\hline \multirow{2}{*}{$\begin{array}{l}\text { Before cortisone } \\
\text { After cortisone }\end{array}$} & $6 \cdot 3$ & I $3 \cdot 8$ & I I 6 & I $3 \cdot 9$ & I I 6 & $10 \cdot 3$ & $24^{\circ} 9$ & 14.0 & $20 \cdot 7$ & \\
\hline & $4 \cdot 3$ & $17 \cdot 4$ & $12 \cdot 2$ & $7 \cdot 9$ & I I'O & $5 \cdot 7$ & $16 \cdot 3$ & $12 \cdot 9$ & $5 \cdot 0$ & \\
\hline
\end{tabular}

Table IV Plasma cortisol levels in 25 glaucomatous patients $(\mu \mathrm{g} / \mathrm{ro0} \mathrm{ml}$ ) before and after administration of oral cortisone

\begin{tabular}{|c|c|c|}
\hline \multicolumn{3}{|c|}{ Primary open-angle glaucoma } \\
\hline \multirow{2}{*}{ Age (years) } & \multicolumn{2}{|c|}{ Plasma cortisol level } \\
\hline & Before cortisone & After cortisone \\
\hline 42 & $20 \cdot 0$ & $12 \cdot 8$ \\
\hline 48 & $9 \cdot 3$ & $3 \cdot 7$ \\
\hline 49 & $24 \cdot 9$ & I6.4 \\
\hline 50 & I $3 \cdot 7$ & $3 \cdot 3$ \\
\hline 55 & $23 \cdot 3$ & 13.9 \\
\hline 57 & $12 \cdot 1$ & $3 \cdot 7$ \\
\hline 60 & $2 \mathrm{I} \cdot 8$ & 18.9 \\
\hline 62 & $13 \cdot 6$ & $13 \cdot 1$ \\
\hline 64 & 13.0 & $5 \cdot 2$ \\
\hline 65 & $21 \cdot 2$ & $17 \cdot \overline{8}$ \\
\hline 73 & $17 \cdot 6$ & $4 \cdot 2$ \\
\hline \multicolumn{3}{|c|}{ Open-angle glaucoma and pseudocapsular exfoliation } \\
\hline 50 & $2 \mathrm{I} \cdot 4$ & $16 \cdot 9$ \\
\hline 56 & $14 \cdot 8$ & $3 \cdot 1$ \\
\hline 58 & $17 \cdot 5$ & $9 \cdot 2$ \\
\hline 60 & I I 0 & $12 \cdot 2$ \\
\hline 65 & $25 \cdot 6$ & $16 \cdot 9$ \\
\hline 66 & $14 \cdot 2$ & I I $\cdot$ I \\
\hline 68 & $17 \cdot 1$ & 3.7 \\
\hline 70 & $20 \cdot 0$ & I $3 \cdot 1$ \\
\hline 72 & $18 \cdot 7$ & $5 \cdot 3$ \\
\hline \multicolumn{3}{|c|}{ Chronic angle-closure glaucoma } \\
\hline 41 & $15 \cdot 0$ & II $\cdot I$ \\
\hline 42 & $9 \cdot 7$ & $3 \cdot 2$ \\
\hline 42 & $18 \cdot 2$ & $5 \cdot 3$ \\
\hline 53 & $24 \cdot 6$ & $15 \cdot 3$ \\
\hline 72 & $4 \cdot 4$ & $4 \cdot 5$ \\
\hline
\end{tabular}

$16.9 \mu \mathrm{g} / \mathrm{ro0} \mathrm{ml}$ and the postsuppression level averaged $9.7 \mu \mathrm{g} / \mathrm{I} 00 \mathrm{ml}$. In 23 out of the 25 patients the plasma cortisol level decreased after orallyadministered corticosteroids and only two patients maintained a steady level. The average decrease resulting from the administration of prednisone in the glaucomatous patients was $6.8 \mu \mathrm{g} / 100 \mathrm{ml}$ (Table IV and Figure).

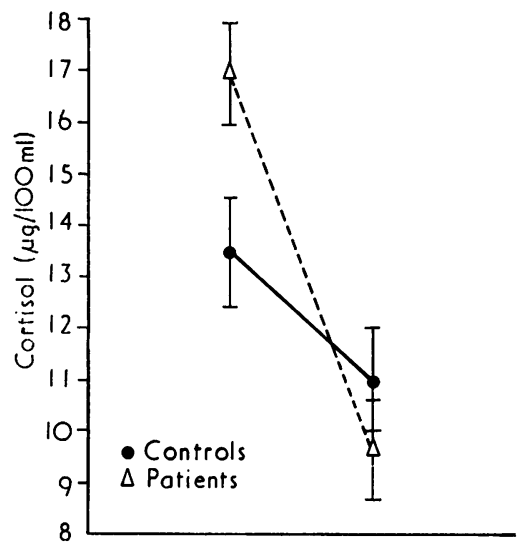

The cortisol suppression response showed no significant differences among the different types of glaucoma, Table IV.

\section{Discussion}

There are reports in the literature concerning the response of glaucomatous patients to systemic corticosteroid administration. There is no uniformity in the reported results. Schwartz and Levene (1972) in one study, and Weinstein and Mori (1972) working independently, found that the initial cortisol levels in glaucomatous patients were higher than in a control group. Furthermore, Schwartz and Levene (1972) found that glaucomatous patients behaved like patients with Cushing's syndrome and did not respond by lowering their serum cortisol levels after administration of oral corticosteroids. Becker and others (1973), however, found that in their glaucomatous patients, oral cortisone administration caused a marked lowering of the plasma cortisol level, that is, their glaucoma- 
tous patients were highly sensitive to the cortisol suppression test.

In a more recent publication, Rosenberg and Levene (1974) supported Becker's earlier finding, and reported a significant reduction in plasma cortisol levels in their glaucomatous patients compared with normal subjects after oral administration of corticosteroids.

We found that the initial serum cortisol level was higher in glaucomatous patients compared with a control group $(\mathrm{I} 6.9 \mu \mathrm{g} / \mathrm{I} 00 \mathrm{ml}$ compared with $13.4 \mu \mathrm{g} / 100 \mathrm{ml}$ ). This finding correlates with those quoted by Weinstein and Mori (1972) and Schwartz and Levene (1972) for White patients.

The suppression of plasma cortisol levels after orally-administered cortisone was more marked in glaucomatous patients than in the control group, an average decrease by $7.0 \mu \mathrm{g} / 100 \mathrm{ml}$ in glaucomatous patients and only $2.5 \mu \mathrm{g} / 100 \mathrm{ml}$ in the control group. Becker and others (1973) and Rosenberg and Levene (1974) reported similar findings.

According to Levene and Schwartz (1968), people in whom the intraocular pressure rises in response to the topical administration of corticosteroids, behave like patients with Cushing's syndrome as far as their response to systemic administration of corticosteroids is concerned. Therefore, the glaucomatous patients who responded markedly to the cortisol suppression test should not be topical corticosteroid responders. The response to topical corticosteroids could not be measured in the patients in our study as they all had advanced glaucoma and were on full medical treatment.

In this group of Black patients, therefore, a definite reduction of plasma cortisol levels indicates that corticosteroid suppression occurred both in the control subjects and the glaucomatous patients. The difference between cortisol levels in control and glaucomatous patients before initiation of the test dose of cortisone is significant to a 99 per cent confidence limit. There was no statistical difference between the final suppressed levels of both groups ( $10.9 \mu \mathrm{g} / \mathrm{ro0} \mathrm{ml}$ as compared with $9.9 \mathrm{~g}$ per cent), see Figure.

However, the fall in the level of the plasma cortisol is the result of suppression which varied significantly $(\mathrm{P}>0.00 \mathrm{I})$ when comparing glacomatous patients with the controls (Figure).

\section{Summary}

Plasma cortisol suppression was measured in 25 Black glaucomatous patients and in 19 Black patients of similar age and sex, but without glaucoma, who acted as controls. Initial serum cortisol levels were found to be slightly higher in the glaucomatous group. The response to systemically-administered cortisone was statistically more marked in the glaucomatous patients compared with the control group.

\section{References}

BECKER, B., PODOS, S. M., ASSEF, C. F., and COOPER, D. G. (1973) Amer. J. Ophthal., 75, 73

LEVENE, z. R., and SCHWARTZ, B. (I968) Arch. Ophthal., 80, 46 I

Luntz, м. н. (1973) S. Afr. Arch. Ophthal., r, 13 I

MURPHY, B. P. (1967) f. clin. Endocr., 27, 973

- ENGElBERG, w., and PATTE, C. z. (1963) Ibid., 23, 293

rosenberg, S., and LeVENe, R. (1974) Arch. Ophthal., 92, 6

SCHWARTZ, B., and LEVENE, R. (1972) Ibid., 87, 369

WeinsteIn, P., and MORI, E. (1972) Klin. Mbl. Augenheilk., 16r, 277 